\title{
木質系バイオマス混焼の利用可能性
}

\author{
学生員 牧野 陽祐* 正 員 加藤 丈佳* \\ 正 員 鈴置 保雄*
}

\section{Potential of Co-firing of Woody Biomass in Coal Fired Power Plant}

Yosuke Makino*, Student Member, Takeyoshi Kato*, Member, Yasuo Suzuoki*, Member

\begin{abstract}
Taking the distributing woody biomass supply into account, this paper assesses the potential of a co-firing of woody biomass in utility's coal power plant from the both energy-saving and economical view points. Sawmill wastes, trimming wastes from fruit farms and streets, and thinning residues from forests in Aichi Prefecture are taken into account. Even though transportation energy is required, almost all of woody biomass can be more efficiently used in co-firing with coal than in a small-scale fuel cell system with gasification as a distributed utilization. When the capital cost of fuel cell system with $25 \%$ of total efficiency, including preprocess, gasification and power generation, is higher than $170 \times 10^{3} \mathrm{yen} / \mathrm{kW}$, almost all of thinning residues can be more economically used in co-firing. The cost of woody biomass used in co-firing is also compared with the transaction cost of renewable power in the current RPS scheme. The result suggests the co-firing of woody biomass in coal fired power plant can be feasible measure for effective utilization of woody biomass.
\end{abstract}

キーワード : 木質系バイオマス, 石炭火力, 混焼, 燃料電池

Keywords: woody biomass, coal fired power plant, co-firing, fuel cell

\section{1. はじめに}

木質系バイオマスはエネルギー密度が低く，しかも排出 地点が分散しているため, 谷のエネルギー利用においては 輸送エネルギーや輸送費用が大きいことが問題とされてい る。弚のため, 排出地点ごとでガス化して燃料電池におけ る発電に利用するなどの小規模・分散システムにおける利 用が有効とされている。しかし，石炭火力における混焼や 将来的にはガス化複合発電などの大規模・集中的なシステ ムは, 小規模システムと比較して本質的にエネルギー効率 が高く，周辺の木質系バイオマスの分布によっては経済的 にも有効な利用方法となる可能性がある。したがって，木 質系バイオマスの最適な利用方法については，地域の木質 系バイオマス賦存量の分布に基づき，輸送エネルギーや輸 送費用を考慮して統計的に評価する必要がある。

本論文では，木質系バイオマスの大規模・集中的な利用方 法として既設の石炭火力における混焼に着目し，地域ごと の賦存量を考慮して，光の省エネ性及び経済性を評価した。 まず, 愛知県を対象として市町村別に製材所廃材, 果樹剪

\footnotetext{
名古屋大学大学院工学研究科

干 464-8603 名古屋市千種区不老町

Graduate School of Engineering, Nagoya University

Furo-cho, Chikusa-ku, Nagoya 464-8603
}

定枝，街路樹剪定枝および間伐残材の賦存量調査を行った。 次に，省エネ性の評価として，混焼による一次エネルギー削 減量が, 輸送および乾燥に必要な合計エネルギーよりも大 きくなる木質系バイオマスの利用可能量 , さらにガス化+ 燃料電池における小規模 - 分散的な利用よりも効率的とな る木質系バイオマスの利用可能量を算定した。また，経済 性について, 賦存量は多いが最も高コストと考えられる間 伐残材を対象として, ガス化 +燃料電池の設備費や, 現在の RPS 法における新エネルギー等の発電電力の取引価格を指 標とした評価を行った。矢の際，森林の持つ多面的機能の 発揮という外部効果を考慮した。以上の検討を通じて, 石 炭火力における木質系バイオマス混焼の利用可能性につい て，省エネ性及び経済性の観点から統計的に評価した。

\section{2. 愛知県の木質系バイオマス賦存量}

愛知県内の 87 市町村を対象として, 文献調査を中心とし て, 以下のように各種木質系バイオマスの賦存量を算定し た。また，市販の地図ソフトを用いて各市町村から石炭火 力までの輸送経路を決定した。

〈2: 1〉 製材所廃材の算定方法 2002 年における県の 国産および外材の素材入荷量 ${ }^{(1)}$ に基づき，比例換算によっ て各製材所の素材入荷量を算定した。本来ならば，製材所 の規模を反映させるべきであるが, 製材所規模についての 
データが得られなかったため，本論文では 1 製材所あたり の規模は同じと想定して算定している。なお，各市町村に おける製材所の総数は電話帳から確認した。次に，製材所 からの各種木質残廃材の発生量および光の利用方法に関す るアンケート調査結果 ${ }^{(2)}$ に基づき，燃料および焼・棄却され るかさ体積としての廃材排出量 $\left(\mathrm{m}^{3} / \mathrm{yr}\right)$ を算定した。さら に,素材別のかさ比重 ${ }^{(3)}$ を考慮して重量換算の排出量 $(\mathrm{t} / \mathrm{yr})$ を算定した。製材所廃材の含水率を $80 \%$ (乾量基準) と想 定して低位発熱量原単位を $8,574 \mathrm{~kJ} / \mathrm{kg}$ とし, 発熱量換算の 製材所廃材の排出量を算定した。

〈2. 2〉果樹剪定枝の算定方法 2001 年における各市 町村の果樹種ごとの栽培面積 (4) と, 果樹剪定枝の排出量原 単位に関するアンケート調査結果 ${ }^{(5)} に$ 基づき，市町村ごと の果樹剪定枝の排出量 $(\mathrm{t} / \mathrm{yr})$ を算定した。また, 果樹剪定 枝の含水率を $100 \%$ (乾量基準) と想定して低位発熱量原単 位を $7,465 \mathrm{~kJ} / \mathrm{kg}$ として，発熱量換算の排出量を算定した。

〈2 3〉 街路樹剪定枝の算定方法 街路樹剪定枝につ いては, 全国 16 都市の街路樹本数 ${ }^{(6)}$ に基づき排出量を算 定した。まず, 街路樹の本数が得られた都市について, 人 口との相関関数を定式化した結果，人口 1 万人あたりの高 木本数は 465 本となり，この值を用いて各市町村の街路樹 本数を算定した。次に，1999 年度における横浜市の街路 樹剪定枝の排出量に基づき, 横浜市の街路樹本数に対する 比例換算によって検討対象地域の各市町村からの街路樹剪 定枝の排出量 $(\mathrm{t} / \mathrm{yr})$ を算定した。また，街路樹剪定枝の含 水率を $100 \%$ (乾量基準) と想定して低位発熱量原単位を $7,465 \mathrm{~kJ} / \mathrm{kg}$ とし，発熱量換算の街路樹剪定枝を算定した。

〈2.4〉間伐残材の算定方法

〈2. 4. 1〉 現状の発生量 平成 14 年度の愛知県の間伐 実績 (7)によると，間伐実施面積は約 2,840 ha であり，間伐 材の素材換算量は約 $60,600 \mathrm{~m}^{3}$ である。また，間伐材のう ち利用されているものは約 $24,800 \mathrm{~m}^{3}$ である。間伐材のう ち素材として利用可能な部分の割合を $60 \%{ }^{\left({ }^{8}\right)}$ とすると, 間 伐材発生量は約 101,000 $\mathrm{m}^{3}$ となる。未利用分を全て間伐残 材とすると，間伐残材発生量は約 $76,200 \mathrm{~m}^{3}$ となり，間伐 残材発生率は $75.5 \%$ となる。

〈2.4.2〉森林管理による潜在的発生量 現状で間伐 が行われていない森林も含め, 愛知県内の全ての人工林針 葉樹 (スギ，ヒノキ) について間伐が行われた場合の間伐 残材賦存量を算定した。愛知県では他県と比べて高龄級の 森林の割合が高く，森林管理が必要な森林は高龄級の森林 において多く存在していると考えられる。このような森林 で森林管理をする場合に 1 ha あたりで発生する間伐残材の 量は, 低齡級 (スギでは 4〜7齢級, ヒノキでは 4〜8 齡級) の森林に対して行われる通常の間伐で発生する量とは大き く異なることが考えられる。乥こで高龄級間伐と通常の間 伐とを区別して間伐残材賦存量を算出した。关の際，愛知 県の森林計画書 ${ }^{(9)}$ に基づき，低齢級の森林では 10 年周期 で, 高齢級の森林では 20 年周期で, $20 \%$ のか間伐される と想定した。
愛知県林業統計書における樹種別齡級別の森林蓄積を用 いて,年間の間伐材発生量 $\left(\mathrm{m}^{3} / \mathrm{yr}\right)$ を算出し,さらに,スギ及

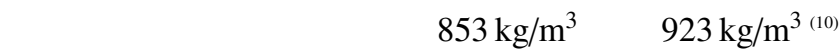
として,重量換算の間伐材発生量 $(\mathrm{t} / \mathrm{yr})$ を算定した。次に， 年間の間伐材発生量に間伐残材発生率を乗じ年間の間伐残 材賦存量を算定した。なお，森林管理が行われ間伐材の発 生量か増加した場合でも間伐残材の発生率は現状と同じと し，現状での値 $(75.5 \%)$ を用いた。上記の計算を市町村 別に行い，市町村別の間伐残材の賦存量を算定した。

また，間伐残材の含水率を $100 \%$ (乾量基準) と想定し て低位発熱量原単位を $7,465 \mathrm{~kJ} / \mathrm{kg}$ とし, 現状および森林管 理による潜在的な間伐残材について，発熱量換算の排出量 を算定した。

〈2.5〉賦存量の算定結果上述の方法により, 各種 木質系バイオマスの排出量を算定した。表 1 に木質系バイ オマス賦存量の重量換算と発熱量換算を示す。回収が容易 な製材所廃材, 果樹剪定枝および街路樹剪定枝の排出量は 少ない。一方，間伐残材は，現状でも $68 \mathrm{kt} / \mathrm{yr}$ と他の木質 系バイオマスと比較して排出量が多い。さらに，森林管理 によって現在は間伐が行われていない森林からの潜在的発 生量も含めると賦存量は $218 \mathrm{kt} / \mathrm{yr}$ となり，現状の発生量の 3.2 倍に増加する。

製材所廃材，果樹剪定枝および街路樹剪定枝の発熱量換算 の賦存量の合計は $222 \mathrm{TJ} / \mathrm{yr}$ であり，この值は平成 13 年度の 碧南火力 5 号機 1,000 MW の石炭消費量 (約 50,000 TJ/yr)

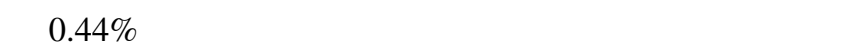
含めると, 全木質系バイオマスの発熱量は約 $1,850 \mathrm{TJ} / \mathrm{yr}$ と なり，1,000 MW の石炭消費量の $3.69 \%$ に相当する。石炭 火力において混焼可能なバイオマスの比率はエネルギー換 算て数\%程度と考えられており ${ }^{(1)}$ ，愛知県における木質系 バイオマスの賦存量は, 大規模な石炭火力における混焼と しては適量と考えられる。

次に，これらの木質系バイオマスの混焼によって得られ る電力を算出した。混焼率が低いため, 発電効率 (発電端 $\left.40 \%{ }^{(11)}\right)$ は変化せず，また，木質系バイオマスの破砕等の前 処理を含めた所内動力も石炭のみの場合 $\left(5.5 \%{ }^{(12)}\right)$ と同じ と想定すると, 全木質系バイオマスを利用した場合の発電量

表 1 木質系バイオマスの賦存量

Table 1. Potential supply of woody biomass.

\begin{tabular}{|l|r|r|}
\hline & $\begin{array}{c}\text { weight } \\
(\mathrm{t} / \mathrm{yr})\end{array}$ & \multicolumn{1}{|c|}{$\begin{array}{c}\text { energy } \\
(\mathrm{TJ} / \mathrm{yr})\end{array}$} \\
\hline sawmill wastes & $\mathbf{4 , 8 8 9}$ & $\mathbf{4 2}$ \\
\hline $\begin{array}{l}\text { trimming wastes } \\
\text { from fruit farms }\end{array}$ & 20,883 & 156 \\
\hline $\begin{array}{l}\text { trimming wastes } \\
\text { from streets }\end{array}$ & 3,180 & 24 \\
\hline \hline Sub total & $\mathbf{2 8 , 9 5 2}$ & $\mathbf{2 2 2}$ \\
\hline $\begin{array}{l}\text { thinning residues } \\
\text { (current) }\end{array}$ & 67,972 & $\mathbf{5 0 7}$ \\
\hline $\begin{array}{l}\text { thinning residues } \\
\text { (potential) }\end{array}$ & 150,024 & 1,120 \\
\hline \hline thinning residues (total) & $\mathbf{2 1 7 , 9 9 6}$ & $\mathbf{1 , 6 2 7}$ \\
\hline TOTAL & $\mathbf{2 4 6 , 9 4 8}$ & $\mathbf{1 , 8 4 9}$ \\
\hline
\end{tabular}




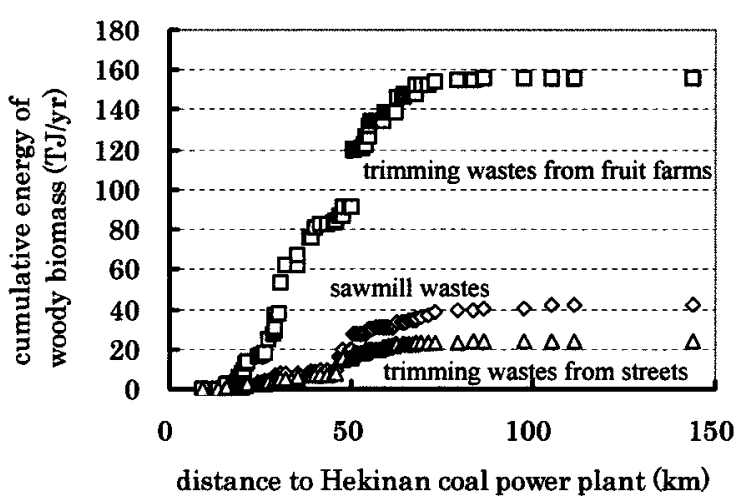

(a) Sawmill wastes and trimming wastes

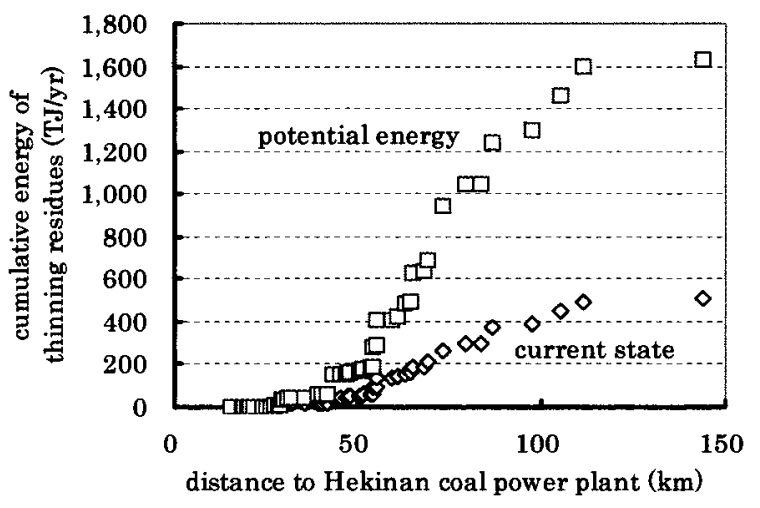

(b) Thinning residues

図 1 石炭火力までの輸送距離と木質系バイオマス の累積発熱量との関係

Fig. 1. Relation between transportation distance to coal fired power plant and cumulative amount of woody biomass.

は約 $194 \mathrm{GWh} / \mathrm{yr}$ となる。この值は，RPS 法による中部電 力の平成 16 年度の新エネルギー導入義務量 (約 $390 \mathrm{GWh}$ ) の約 50\%に相当する。

各市町村における各木質系バイオマスの排出量と石炭火 力までの輸送経路の距離との関係を図 1 に示す。同図 (a) に 示す製材廃材および剪定枝の場合, 片道の輸送距離が $80 \mathrm{~km}$ 以内の市町村からの排出量が多い。一方，同图 (b) に示す 間伐残材の場合，輸送距離が 50〜100 km の市町村の間伐 残材賦存量が多い。

\section{3. 省エネ性評価}

〈3.1〉輸送エネルギーの算定方法 木質系バイオマ スを石炭火力において混焼する場合，エネルギー的に損失 とならないためには，少なくとも輸送エネルギーと乾燥エ ネルギーの合計値よりも，発電による石炭分の一次エネル ギー削減量の方が大きい必要がある。光こで本論文では， 以下のように，石炭火力までの木質系バイオマス輸送エネ ルギーおよび乾燥エネルギーを算定した。

市町村単位で集計したバイオマス $\mathrm{n}$ の排出量 $B_{\mathrm{n}}\left(\mathrm{m}^{3} / \mathrm{yr}\right.$ または $\mathrm{t} / \mathrm{yr})$ に対し，トラック 1 台あたりの輸送可能量を $F_{\mathrm{n}}$ $\left(\mathrm{m}^{3} /\right.$ 台または $\mathrm{t} /$ 台 $)$ とすると, 輸送に必要なトラック延べ 台数は $B_{\mathrm{n}} / F_{\mathrm{n}}$ となる。次に, トラックの燃費 $G$ を $3 \mathrm{~km} / \mathrm{L}$,
軽油の発熱量 $Q$ を $38.2 \mathrm{MJ} / \mathrm{L}$ として, 市町村 $A$ から石炭火 力までの輸送経路 $L_{\mathrm{A}}(\mathrm{km})$ を用いると, トラックの往復 に必要な輸送エネルギー $T_{\mathrm{A}} \quad(\mathrm{MJ} / \mathrm{yr})$ は次式のように表さ れる。

$$
T_{\mathrm{An}}=\left(\frac{B_{\mathrm{n}}}{F_{\mathrm{n}}}\right) \times\left(\frac{L_{\mathrm{A}}}{G} \times 2\right) \times Q
$$

なお，バイオマス排出地点は各市町村内で分散している が, 多くの市町村に関して, 市町村内の輸送距離よりも市 町村から碧南火力までの輸送距離の方が長いと考えられる。 乥こで本研究では, 市町村内の輸送距離については, 光れ ぞれの排出地点からの距離を個別に算定するのではなく， 各市町村の市役所・町村役場を弚の代表地点として平均的 な輸送距離を用いている。

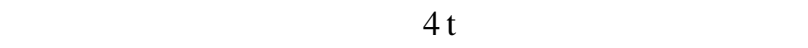
のように発生量を見かけ体積で算出していることから，標 準的な荷台面積を考慮して， $F_{\mathrm{n}}=8 \mathrm{~m}^{3} /$ 台と想定した。果 樹·街路樹剪定枝については, 剪定枝粉砕処理車による輸送 を想定し， $F_{\mathrm{n}}=1.6 \mathrm{t} /$ 台と想定した。間伐残材については， 枝葉を結束してからトラックに積み込むという輸送方法の 実測値 ${ }^{(1)}$ に基づき, 単位容積あたりの重量を $0.437 \mathrm{t} / \mathrm{m}^{3}$ と し, $F_{\mathrm{n}}=3.5 \mathrm{t} /$ 台と想定した。

〈3.2〉乾燥用エネルギーの算定方法 木質系バイオマ スは含水率 $25 \%$ (乾量基準) まで乾燥された後に利用され ると想定した。水の蒸発熱を $2,512 \mathrm{~kJ} / \mathrm{kg}(600 \mathrm{kcal} / \mathrm{kg})$ ，ボ イラの燃焼効率 $\eta_{\mathrm{B}}$ を $80 \%$ と想定し, 含水率 $M \%$ （乾量基 準) のバイオマスを $25 \%$ まで乾燥するために必要なエネル ギー量 $D_{\mathrm{M}}(\mathrm{kJ} / \mathrm{kg}$, m.c. basis) を次式によって算出した。

$$
D_{\mathrm{M}}=\frac{M-25}{100+M} \times \frac{2,512}{\eta_{\mathrm{B}}} \text {. }
$$

〈3.3〉混焼に利用可能なバイオマス量 混焼時の発電 効率 $\eta_{\mathrm{C}}$ を $37.8 \%$ (発電端効率 $40 \%$, 所内動力 $5.5 \%$ ) と想 定し, 利用時における含水率 $25 \%$ (乾量基準) の木質系バ イオマスの量を $B_{\mathrm{n}}^{\prime}$, 発熱量を $Q_{25}$ として，混焼による一次 エネルギー削減量 $E_{1}(\mathrm{MJ} / \mathrm{yr})$ を次式によって算出した。

$$
E_{1}=B_{\mathrm{n}}^{\prime} \times Q_{25}-\left(T_{\mathrm{An}}+B_{\mathrm{n}} \times D_{\mathrm{M}}\right)
$$

愛知県内の 87 市町村の各木質系バイオマスについて $E_{1}$ を算出した。关の結果, 全ての木質系バイオマスについて $E_{1}$ は正となった。すなわち, 輸送エネルギーや乾燥エネル ギーを考慮しても，愛知県内で排出される全ての木質系バ イオマスは, エネルギー的に損失とならずに石炭火力にお いて混焼可能であると考えられる。

〈3. 4〉 ガス化+燃料電池との比較 木質系バイオマ スを市町村単位で分散的にエネルギー利用する技術として ガス化+燃料電池システムを想定し，一次エネルギー削減 量に関して，石炭火力における湝焼との比較を行った。一 般に, ガス化効率は 70〜 75\% (13)(14) , 燃料電池による発電効 率は 45 55\%程度である。さらに，木質系バイオマスの破 砕のための動力や, 市町村内での木質系バイオマスの輸送 
を考慮して, 燃料電池の発電効率 $\eta_{\mathrm{FC}}$ は $25 \sim 35 \%$ と想定し た。なお，燃料電池の排熱は，木質系バイオマスの乾燥用 に利用されることも考えられるが，本論文では，ガス化に 必要な熱として利用されると想定した。

ガス化+燃料電池による一次エネルギー削減量と上述の $E_{1}$ とを比較し，石炭火力において混焼した方がエネルギー 的に有利となる木質系バイオマスの割合を算定した。关の 結果， $\eta_{\mathrm{FC}}=33 \%$ 以下の場合，全ての木質系バイオマスに 関して , 石炭火力における涮焼の方か効率的であった。 $\eta_{\mathrm{FC}}$ が34\%を超えると，混焼の方か効率的となる木質系バイオ マスの割合は減少し， $\eta_{\mathrm{FC}}=35 \%$ の場合には，全木質系バ イオマスの約 $20 \%$ が混焼に利用するよりもガス化+燃料電 池において利用した方か効率的となった。

なお，ガス化+燃料電池システムは，小規模でも高効率 な発電システムであることが特徵であるため, 本研究では, 規模によらず発電効率は一定と考え，各市町村に 1 ヶ所ず つ導入されるものと想定している。この場合，ガス化+燃 料電池の発電効率を $25 \%$ とすると, 各市町村の発電規模は $0.2 \sim 2.3 \mathrm{MW}$ となる。したがって, 発電規模が数 $\mathrm{kW} に も$ 満たないような市町村に関しては, より長距離の木質系バ イオマスの輸送が必要であり，輸送エネルギーや輸送コス 卜の増加のために , 石炭火力における泿焼への利用の優位 性がさらに増すものと考えられる。

\section{4. 間伐残材の経済的価值}

〈4: 1〉間伐残材価格の算定方法 木質系バイオマスの うち，最も賦存量の大きい間伐残材に関して，石炭火力に おける混焼において経済的に利用可能な賦存量を算定した。 間伐残材を利用するために必要な費用として，伐採・搬出 費用と石炭火力までの輸送費用を考慮した。伐採・搬出費 用は全てエネルギー利用のための間伐残材で負担されると 考えた。ただし，間伐材のうち $24.5 \%$ は, 製材・加工材や 丸太材等, エネルギー以外の目的で利用されて利益が得ら れることを考慮して(7)，产の利益分を伐採・搬出費用と輸 送費用から差し引くことにより，石炭火力において利用す る際の間伐残材の価格を算出した。

〈4.2〉伐採・搬出費 愛知県林野庁の提供資料によ り，伐採・搬出費用は 247,000 円/ha と見積もられている。 1ha の間伐によって発生する間伐残材は $31.1 \mathrm{t} / \mathrm{ha}$ であるた め, 間伐残材を $1 \mathrm{t}$ 発生させるのに必要な費用は 7,950 円/ $\mathrm{t}$ となる。

〈4 3 輸 送 費 輸送の際に必要な燃料費と人件費と を合わせて輸送費とする。輸送は $4 \mathrm{t}$ トラックによって行 われるものとし, トラックの燃費 $G$ を $3 \mathrm{~km} / \mathrm{L}$, 軽油の価格 $C_{1}$ を 86 円 $/ \mathrm{L}$ と想定した。上述のように，トラック 1 台あ たりの輸送可能量 $F_{\mathrm{n}}$ を $3.5 \mathrm{t} /$ 台と想定しており，各市町村 $A$ から石炭火力までの片道輸送距離 $L_{\mathrm{A}}(\mathrm{km})$ を用いて, 間 伐残材 $1 \mathrm{t}$ あたりの燃料費 $C_{\mathrm{t}-\mathrm{f}}$ を次式のように算定した。

$$
C_{\mathrm{t}-\mathrm{f}}=\frac{C_{1}}{G} \times \frac{1}{F_{\mathrm{n}}} \times 2 L_{\mathrm{A}}
$$

次に,トラックドライバーの時間給 $H_{\mathrm{p}}$ を 1,250 円 $/ \mathrm{h}$ (日給 としては 10,000 円/日) , トラックの平均速度 $S_{\mathrm{av}}$ を $30 \mathrm{~km} / \mathrm{h}$ と想定し, 人件費 $C_{\mathrm{t}-l}$ を次式によって算出した。

$$
C_{\mathrm{t}-1}=\frac{H_{\mathrm{p}}}{S_{\mathrm{av}}} \times \frac{1}{F_{\mathrm{n}}} \times 2 L_{\mathrm{A}}
$$

以上から,片道輸送距離 $L_{\mathrm{A}}(\mathrm{km})$ あたりの輸送費 $\left(C_{\mathrm{t}-\mathrm{f}}+\right.$ $\left.C_{\mathrm{t}-1}\right)$ は, $40.2 L_{\mathrm{A}}($ 円 $/ \mathrm{t})$ となる。

〈4 4〉 エネルギー以外の利用による利益 間伐材の径 を9 9 11 cm と想定し，原木価格をスギが 10,000 円 $/ \mathrm{t} ，$ ヒ ノキが 17,000 円 $/ \mathrm{t}^{(15)}$ とする。森林管理によるスギおよびヒ ノキの間伐材発生比は光れ光れ 55\%および $45 \%$ であり，間 伐材の平均原木価格は 13,200 円/t となる。間伐残材の発生 率が $75.5 \%$ であることを用いて, 間伐残材 $1 \mathrm{t}$ あたりの利益 分を求めると 4,280 円 $/ \mathrm{t}$ となる。

〈4 5〉間伐残材価格の算定結果 上述の算定方法に 基づき，石炭火力で発電用燃料として利用する際の間伐残 材価格 $C_{\mathrm{tr}}$ を算定した。兴の結果，愛知県全体での間伐残 材の平均価格は 6,730 円/ $\mathrm{t}$ となった。この值は単位エネル ギーあたりでは 901 円/GJ に相当する。原料炭の輸入価格 が 180 円/GJ ${ }^{(16)}$ 程度であることを考えると，燃料としての 間伐残材価格は非常に高いと言える。

\section{5. 外部効果を含めた経済的価値}

間伐残材のエネルギー利用の外部効果として，森林管理 による森林の多面的機能の発揮が考えられる。森林の多面 的機能には表層崩壞防止効果，水源涵養効果，生物種保全 効果などがあるが，これらの効果の多くは森林管理による 効果額を定量化することは容易ではない。本論文では，検 討の第一段階として, 定量化しやすい表層崩㗒防止効果の みをとりあげた。表層崩壞防止効果の経济的価値は, 森林 管理によって減少する年間の表層崩壊面積を算定し，これ に伴う山腹工事費用の減少分とした。

まず，対象地域において 1 年間に新たに崩噮する面積の 割合を算定した。年度別の全国の崩壊面積の推移 ${ }^{(17)}$ による と, 1 年間に発生する崩壊面積の平均值は 17,334 ha であっ た。この值は平成 15 年度の全国の森林面積 2,514.6 万 ha の $0.0689 \%$ に相当する。

次に，林野庁が昭和 34 年に行った崩壊地調査の結果を参 考にして ${ }^{(18)}$ ，森林管理による崩壊面積の差を算定した。こ の調査によると，主伐の際，択伐方式による伐採が行われて いる森林での崩壊面積は $0.98 \%$,未着手の森林では $1.66 \%$ ， 平均では $1.18 \%$ なっている。択伐の場合と未着手の場合 の崩壊面積割合の比率は, 森林管理がされる場合とされな い場合の崩壊の起こりやすさの比率を表していると考え， この比率の差によって森林管理の有無による表層崩壞防止 効果が表されるとした。ただし, 上述の值は, 調査時まで の累積の崩壊面積であることと, 崩壞が起こっている森林 を選択して調査されている可能性が高いため, 光れ光れの 崩壊面積割合の絶対値が通常よりも大きくなっていること が考えられる。乥こで, 前述の 1 年間に新規に崩壊する面 
積の割合 $0.0689 \%$ を基準にして, 後述の崩壊面積の割合は 森林管理の有無による比率のみを用いた。

以上の想定に基づき，森林管理がされる場合とされない 場合の一年間に発生する崩壊面積の差を求めた。全森林面 積に対する 1 年間で発生する崩壊面積の割合は, 森林管理 がされる場合が $0.0572 \%(=0.0689 \times 0.98 / 1.18)$ ，森林管 理がされない場合が $0.0970 \%(=0.0689 \times 1.66 / 1.18)$ と なり，兴の差は $0.0398 \%$ でる。山腹工事費用は崩壊面積 1 ha あたり 8,690 万円/ha ${ }^{(19)}$ とすると，森林管理の有無に よる森林 1 ha あたりの年間工事費用の差は 34,500 円/ha と なる。 1 ha の間伐によって発生する間伐残材は $31.1 \mathrm{t} / \mathrm{ha}$ で あるので, 間伐残材を $1 \mathrm{t}$ 収集することによる表層崩壊防止 効果の経济的価値は 1,110 円 $/ \mathrm{t}$ となる。

また，この值を上述の間伐残材価格から差し引くことに より，森林管理による外部効果を考慮した間伐残材の価格 $C_{\mathrm{tr}}$ は, 愛知県全体の平均で 5,620 円/t $(753$ 円 $/ \mathrm{GJ})$ となっ た。すなわち，森林管理による表層崩壞防止効果を考慮す ることによって, エネルギー源としての間伐残材の価格 $C_{\mathrm{tr}}$ を $16 \%$ 安く見積もることができる。

今後, 表層崩壊防止効果以外の外部効果に関しても経済 的価値を算出し，評価に含める予定である。

\section{6. 間伐残材を利用した混焼の経済性評価}

〈6.1〉間伐残材の発電コスト 石炭火力において利用 する際の間伐残材の価格 $C_{\mathrm{tr}}$ (円/GJ) と，木質系バイオマス の破砕等の前処理を含む混焼システムの追加的な設備費 $C_{\mathrm{C}}$ とから，木質系バイオマスを混焼に利用する場合の発電コス 卜を算定した。上述のように，混焼を行っても石炭火力の発 電効率は低下せず, $\eta_{\mathrm{C}}=37.8 \%$ とした。また , $C_{\mathrm{C}}=20,000$ 円 $/ \mathrm{kW}^{(20)}$ ，耐用年数 $Y=20$ 年，負荷率 $L F=80 \%$ と想定 し，次式によって間伐残材を用いた場合の発電コスト $C_{\mathrm{E}}$ (円/kWh) を算出した。

$$
C_{\mathrm{E}}=\frac{C_{\mathrm{C}}}{Y \times 8,760 \times L F}+\frac{C_{\mathrm{tr}}}{\eta_{\mathrm{C}}} \times \frac{3,600}{10^{6}}
$$

森林管理による外部効果を含める場合と含めない場合の 発電コストと間伐残材賦存量との関係を図 2 に示す。外部 効果を含めない場合，発電コストは 5.62〜12.2 円 $/ \mathrm{kWh}$ と なり，愛知県全体での平均値は 8.73 円 $/ \mathrm{kWh}$ となった。こ れに対し，外部効果を含めて評価することによって，発電

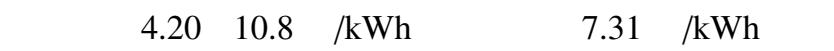
り，間伐残材を利用した発電コス卜を 1.42 円 $/ \mathrm{kWh}$ 低く見 積もれることがわかった。

〈6. 2〉 ガス化+燃料電池との比較 間伐残材をガス 化+燃料電池に利用する場合の発電コストについては, 将 来技術であるガス化 +燃料電池の設備費 $C_{\mathrm{FC}}$ によって大き く異なる。并こで, $C_{\mathrm{FC}}$ を 1 30 万円 $/ \mathrm{kW}$ と変化させ，石 炭火力における混焼の方が発電コストが安くなる間伐残材 の割合を算定した。ただし,ガス化+燃料電池の設備費 $C_{\mathrm{FC}}$ には木質系バイオマスを破砕する費用も含むものと想定し た。なお，ガス化+燃料電池に利用する場合の間伐残材の

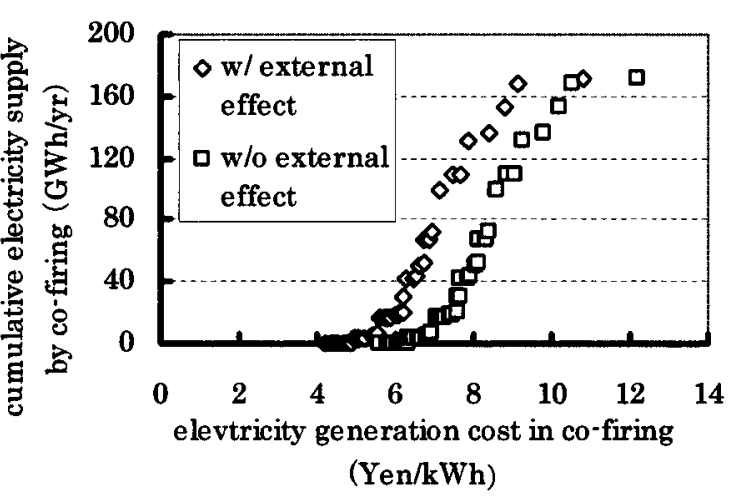

図 2 石炭火力における木質系バイオマス混焼の 発電コスト

Fig. 2. Electricity generation cost of biomass co-firing in coal fired power plant.

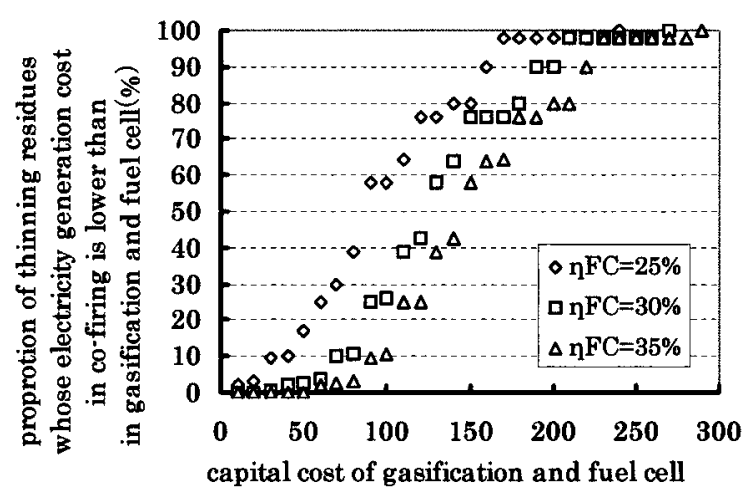

$\left(10^{3} \mathrm{Yen} / \mathrm{kW}\right)$

図 3 ガス化+燃料電池の設備費に対する混焼と ガス化 + 燃料電池との経済性の変化

Fig. 3. Economy of co-firing with coal as a function of facility cost of FC system with gasifier.

価格は, 上述の $C_{\mathrm{tr}}$ から市町村ごとに輸送費用を差し引い た値を用いた。また，ガス化 +燃料電池の電池寿命を 4 万 時間 ${ }^{(21)}$, ガス化プロセスを含む発電効率を $25 〜 35 \%$ と想定 し，(6) 式と同樣にして発電コストを算出した。

ガス化+燃料電池の設備費に対して，混焼に利用した方 が有益となる間伐残材の割合を図 3 に示す。ガス化 +燃料 電池の発電効率が $25 \%$ の場合, 設備費が 17 万円 $/ \mathrm{kW}$ 程度 以上であれば, 愛知県で発生する間伐残材のほぼ全てが混 焼に利用した方が経済的にも有利となることがわかった。 また, 将来的にガス化+燃料電池の発電効率が $35 \%$ 程度に なっても，設備費が 23 万円 $/ \mathrm{kW}$ 以上であれば混焼に利用 した方が経済的となった。

〈6.3〉他の新エネルギー発電との比較 RPS 対策と しての間伐残材による混焼を想定し, 上述の混焼の発電コ ストの算定結果と RPS 施行下での新エネルギー等の発電電 力取引価格 ${ }^{222}$ との比較を行った。結果を图 4 に示す。同図 より廃棄物発電等の現状で行われているバイオマス発電や 水力発電の取引価格の大部分は混焼の発電コストと競合し 


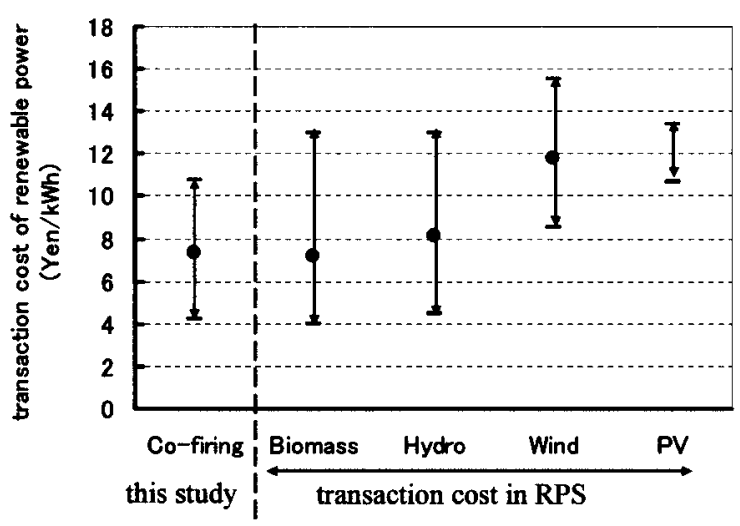

図 4 混焼の発電コストと RPS における新エネルギー 発電電力取引価格との比較

Fig. 4. Comparison between electricity generation cost of co-firing and transaction cost in RPS scheme.

ている。しかし，PV の取引価格に対して，混焼の方が発 電コストが安くなる間伐残材の割合は 100\%である。また， 風力発電との比較でも, 発電コストは混焼の方が安くなる 可能性が高いと考えられる。取引価格の安い廃棄物発電や 水力発電の発電電力だけでは, 新エネルギ一導入義務量を 賄えないと考えられるので, PVや風力発電の代替として, 新エネルギー導入義務量の約 50\%を賄うことができる混焼 は，RPS 対策として経済的にも有効であると考えられる。

\section{7. おわりに}

本論文では，地域の木質系バイオマスの賦存量を算定し， 石炭火力における混焼によるエネルギー利用の省エネ性お よび経済性を評価した。主な知見は以下のとおりである。

(1) 愛知県内の木質系バイオマスの賦存量は年間 1,850 TJ であり，全てを混焼に利用する場合，194 GWh の発 電量となる。この值は, 検討地域の電力会社における RPS 法下での新エネルギー導入義務量の約 $50 \%$ に相当する。

(2) 愛知県内で発生する木質系バイオマスのほぼ $100 \%$ について，輸送エネルギーを考慮しても，ガス化+燃料電 池に利用するよりも石炭火力における混焼に利用した方が 省エネ性の点で有利である。

（3）表層崩壞防止効果という外部効果を考慮すると， エネルギー源としての間伐残材価格は約 16\%安く見積もら れる。

（4） ガス化+燃料電池の発電効率が $25 \%$ の場合，設備 コストが 17 万円 $/ \mathrm{kW}$ 程度以上であれば，愛知県内で発生 する全ての間伐残材について，輸送費用を考慮しても発電 コストは石炭火力における混焼の方が安い。

（５）愛知県内の大部分の間伐残材に関してはRPS 法施 行下における新エネルギー等の発電電力取引価格に対して 経済的に有利である。

今後は, 森林管理による副次的な効果として表層崩壞防 止以外の効果も定量化し，木質系バイオマスの最適エネル ギー利用について検討を行う必要があると考える。また，
RPS 法施行下における新エネルギー等の発電電力取引価格 の分布を調査し，RPS 対策としてのバイオマス混焼の利用 可能性を検討する予定である。

(平成 17 年 2 月 22 日受付，平成 17 年 6 月 6 日再受付)

\section{文献}

（1）農林水産省 Web site： http://www.maff.go.jp/toukei/sokuhou/data/ seizai2002/seizai2002.pdf

（2）伊神裕司・村田光司：「製材工場における木質残廃材の発生と利用」, 森林総合研究所報告, Vol.2, No.2, pp.111-114 (2003)

(3) 辻 直幸・藤井栄治・安藤 努・山吉栄作・舩岡正光 :「植物資源の 活用循環系を創造するための三重県をモデル地域とした検証」, 三重 県工業技術総合研究所研究報告, No.24 (2000)

（4）農林水産省 Web site: http://www.tdb.maff.go.jp/toukei/a02smenu2?TokID $=$ D003\&TokKbn=B\&TokID1=D003B2001-010

( 5 ) T. Sano and S. Miura: "A Study on the Use Possibility of Woody Biomass Energy According to an Area", Proc. of 22th JSER, pp.329-334 (2003) (in Japanese)

佐野貴司・三浦秀一：「木質バイオマスエネルギーの地域別利用可 能性に関する研究」,第 22 回エネルギー・資源学会研究発表会講演 論文集, pp.329-334 (2003)

（6）京都市 Web site：http://www.city.kyoto.jp/kensetu/ryokusei/keikaku/keikaku_ frame_7_1.html

（7）愛知県農林水産部林務課 : 平成 14 年度愛知県林業統計書, p.52 (2003)

（8）本多淳裕：バイオマスエネルギー, 省エネルギーセンター (1986)

(9) 愛知県農林水産部林務課: 尾張西三河森林計画変更計画書 (2003)

（10）林野广：平成 12 年度バイオマス資源の利用手法に関する調査報告 書 (2001)

(11) 新エネルギー・産業技術総合開発機構 : バイオマスエネルギー高効 率転換技術開発 石炭・木質バイオマス混焼技術の研究開発 (2003)

（12）経済産業省資源エネルギー庁電力・ガス事業部：電力需給の概要, p.221 (2002)

(13) K. Dowaki and S. Mori: "An operating evaluation concerning the biomass gasification cogeneration system", Proc. of 21th JSER, pp.277-282 (2002) (in Japanese)

堂脇清志・森 俊介 : 「バイオマスガス化コージェネレーションシ ステムの運転評価」, 第 21 回エネルギー・資源学会研究発表会講演 論文集, pp.277-282 (2002)

(14) 電力中央研究所 : 木質系バイオマス発電技術の動向と実用化に向け た研究課題, 電力中央研究所報告 (2003)

(15) 岐阜県 Web site : http://www.pref.gifu.jp/s11548/tyutu/6.htm

(16) 省エネルギーセンター：エネルギー・経済統計要覧 (2003)

（17）日本治山治水協会 : 治山事業 60 年史, 中央公論事業出版 (1973)

（18）水利科学研究所 : 森林経営と保全に関する基礎調査報告書, pp.172-174 (1971)

(19) 三菱総合研究所 : 地球環境人間生活にかかわる農業及び森林の多面 的な機能の評価に関する調査研究報告書 (2001)

(20) Office of Utility Technologies, Energy Efficiency and Renewable Energy, U.S, DOE and EPRI: Renewable Energy Technology Characterizations, p.242 (1997)

(21) 溶融炭酸塩型燃料電池発電システム技術研究組合 Web site : http://www1.ttcn.ne.jp/ MCFC/content5.html

(22) RPS 法 Web site : http://www.rps.go.jp

牧 野 陽 祐 (学生員) 1981 年 12 月 6 日生。2004 年 3 月名

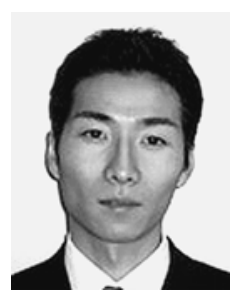
古屋大学工学部電気電子工学科卒業。同年 4 月名 古屋大学大学院工学研究科電子情報システム専攻 電気工学分野博士課程前期課程に進学。現在に至 る。木質系バイオマスに関する研究に従事。エネ ルギー・資源学会会員。 
加 藤 丈 佳 (正員) 1996 年 3 月名古屋大学大学院工学研究科 博士課程後期課程修了。同年 4 月名古屋大学理工 科学総合研究センター助手, 現在に至る。2002 年 国際応用システム分析研究所研究員。工学博士。 超伝導システム, エネルギーシステムに関する研 究に従事。エネルギー・資源学会会員。
鈴 置 保 雄 (正員) 1978 年 3 月名古屋大学大学院工学研究科 博士課程後期課程修了。同年 4 月名古屋大学工学 部助手, 同講師, 同助教授を経て, 1995 年 4 月同 大学理工科学総合研究センター教授, 2003 年 4 月 同大学大学院工学研究科教授, 現在に至る。工学 博士。主として, 電気電子材料, エネルギーシス テムに関する研究に従事。IEEE, 応用物理学会, 高分子学会, エネルギー・資源学会会員。 